\title{
ORGANIZATIONAL CULTURE AS A PRECURSOR TO THE PRACTICE OF CORPORATE SOCIAL RESPONSIBILITY: A CONCEPTUAL STANDPOINT
}

\author{
Wobodo C. ${ }^{1}$, Poi G. ${ }^{2}$ and Lebura S. ${ }^{1}$ \\ ${ }^{1}$ Department of Management, Faculty of Management Sciences, Rivers State University, Port \\ Harcourt, Nigeria
}

${ }^{2}$ Department of Business Administration, Faculty of Social and Management Sciences, University of Africa, Toru-Orua, Bayelsa State, Nigeria

Email: chinonyewobodo@gmail.com

\section{Cite this article:}

Wobodo C., Poi G., Lebura S. (2021), Organizational Culture as a Precursor to the Practice of Corporate Social

Responsibility: A Conceptual Standpoint. British Journal of Management and Marketing Studies 4(3), 62-72. DOI: 10.52589/BJMMS-

TKA37NUR.

\section{Manuscript History}

Received: 28 May 2021

Accepted: 5 July 2021

Published: 3 Aug 2021

Copyright $\odot 2020$ The Author(s). This is an Open Access article distributed under the terms of Creative Commons AttributionNonCommercial-NoDerivatives 4.0 International (CC BY-NC-ND 4.0 ), which permits anyone to share, use, reproduce and redistribute in any medium, provided the original author and source are credited.
ABSTRACT: A harmonious relationship between business and society has been acknowledged to be an indispensible framework for a sustainable business performance. This is as no business venture can successfully operate without the society's support, especially in the area of input resources and enabling environment creation which promotes business success and growth. Similarly, the extent to which such harmonious relationship is maintained will to a great extent depends on corporate social responsibility practices by organizations as means of given back to the society voluntarily. On this note, this study seeks to theoretically evaluate the influence of organizational culture in the promotion of corporate social responsibility practices. In line with this objective, literature on the meaning and nature of organizational culture and its dimensions were reviewed, followed by corporate social responsibility and its measures; there after we interlaced organizational culture and corporate social responsibility. Finally, the study concludes that corporate social responsibility display by organizations is a form of voluntary organizational behavior towards the society with the capacity to bring the organization cohesively close to its stakeholders and in the long run stimulates its goal attainment in a sustainable manner. We therefore recommend as follows: i) that organizations while in pursuit of their primary goals should also embrace CSR (ii) that organizations should identify stakeholders' needs before adopting any given CSR approach.

KEYWORDS: Organizational Culture, Culture Taxonomies, Corporate Social Responsibility, Philanthropy 


\section{INTRODUCTION}

Organizations are social system floated to provide solution to societal problem (need) through quality goods and services. However, to effectively and efficiently do this, organizations also depend largely on their external environment for the needed inputs (resources) such as human beings, land and water, mineral and other associated materials which are subsequently transformed and then given back to the society as output (goods or services). This observed interdependency further reinforces the assertion that organizations do not exist in isolation but are mutually dependent with their operating environment (Wobodo, Asawo \& Asawo, 2018; Koontz \& Weihrich, 1999). Similarly, Boafo and Kokuma (2016) added that organizational objectives are inseparable from the society and environments within which their businesses are carried out and as such, it becomes a strategic necessity that why in pursuit of its short-term economic gain, longer-term social and environmental impacts of its practices must be adequately considered. Consequently, it is now a globally established demand that organizations in the cause of their operations protect and care for the environment, especially through various corporate social responsibility practices.

In congruence with the forgoing statements, Mensah (2017) maintained that corporate social responsibility practice is now a salient means through which organizations respond to the social needs and expectations of their host communities. It is associated with the determination of an organization to advance the well-being of the people in their operational environment through voluntary business practices and investment of organizational resources (Charkraborty, 2010). In fact, the demonstration of corporate social responsibility is considered essential for organizations that want to be successful and sustainable in their businesses (Korkchi \& Rombaut, 2006). This discretionary behavior is specifically seen as an essential ingredient for organizational survivability goal. This is as such gesture to a large extent paves way for sustainable and uninterrupted business operations as well as the attendant strategic economic benefits it accrues the organization in the long run. Thus, it is usually aimed at customers and community members in their immediate environment given that they are critical stakeholders and pillars in every business. And of course, their actions affect as well as affected by the actions of the organization. This view is anchored on Freeman (1984) stakeholder's theory which holds that managers must provide benefits to different group of people (e.g., workers, customers, suppliers, local community organizations) whose actions can impact on the firm's outcomes.

In view of these accounts, organizational culture becomes the bedrock on which corporate social responsibility policy can be developed and implemented. Organizational culture plays an indispensible role in the determination of a firm's behavior towards its environment and stakeholders at large, hence provides a framework for its actions and inactions. Therefore, the cultural practices of an organization have the potential to influence its leadership priorities and general performance outcomes (Lee \& Yu, 2004; Kessapidou \& Varsakelis, 2002). In this regard, it can be said that the type of culture practiced by an organization can either impinge or facilitate the realization of its determinable objective. With this in mind, a comprehensive grasp of culture concept would allow members of the organizations to solve problems and improve organizational performance. Scholars like Cameron and Freeman (1991) argue that an organization operating with a strong cultural alignment is usually more effective and productive compare to when it has a weak and disconnected culture. Similarly, improving, maintaining or changing organization culture aids in making organizations more competitive as well as helps in revitalizing declining organizations. 
Leaning on the above, the interest of this paper is to critically $\mathrm{x}$-ray the place of organizational culture in the enthronement of corporate social responsibility practices in the corporate world. In order to achieve the study purpose, extant literature review were explored on each of the study variables, afterwards we determined the relationship between the two variables based on existing theoretical and empirical evidence, and drew conclusion and made relevant recommendations where necessary.

\section{The Nature and Meaning of Organizational Culture (OC)}

Every organization irrespective of its industry scope operates within given self-developed philosophies and practices. Such philosophies and practices however, define the behavior of the organization in terms of its internal and external relationships; which over time becomes a dominant culture of that organization. According to Cameron and Quinn (1999) the success of an organization I s largely dependent on the type of culture that its management has put in place to enable it achieve its purpose. In the same vein, Kandula (2006) contend that due to the fact that organizational culture varies, two different organizations operating in the same environment may share similar strategy but definitely will have different outcomes. This is because organizational culture defines the character of the organization and as such influence the personality and perception of the stakeholders toward the organization. In an attempt to provide a conceptual meaning to organizational culture construct, several scholars have at one point or the other bared their minds.

For instance, organizational culture has been defined as shared values, customs, beliefs, attitudes and patterns of thinking in relation to all individuals in the organization (Mckinnon et al., 2003; O'Reilly \& Chatman, 1996). Accordingly, Greenberg and Baron (2000) posit that it is a mental framework that encompasses shared attitudes, values, norms and expectations shared by the organizational members (Greenberg \& Baron, 2000). For Robbins, DeCenzo and Coulter (2011), it deals with shared values, traditions, principles and means of doing things which determines the way members of the organization behave. Additionally, Yilmaz and Ergun (2008) stated that the culture of an organization is the sum of its fundamental assumptions, values, attitudes and behaviors that is reflected in the actions of its members. Given the respective definitions offered by different scholars, we can deduce that there is no major disparity in their opinions as to what culture is to an organization hence, it is just a matter of semantics.

According to Brooks (2006), a good grasp of the magical influence of culture has the capacity to increase our aptitude to evaluate organizational behavior in order to manage and lead others effectively. Equally, Robbins and Judge (2000) maintain that the organization's culture is the first step in fostering entrepreneurship behavior within an organization and of course, organizational culture serves as a precursor of entrepreneurial orientation strategy required to keep organization ahead of others in the face of rapid internal and external changes in business dynamics. Again, there is no doubt we are in the era of knowledge-based driven economy where organizations are expected to maximize the value of their employees' intellectual expertise through effective knowledge management. As observed in Dasanayaka and Mahakalanda (2008), effective management of intellectual assets requires a culture that promotes employees' intellectual participation and facilitates both individual and organizational learning, new knowledge creation and application, and the willingness to share knowledge with others. So, without the adoption of a culture that is compatible with this 
changing trend, organizations may end up incurring unexpected intellectual loss especially by attrition.

Furthermore, Schein (1990) hypothesized that the culture of an organization does not just emerge on the basis of mere choice by the organizational leaders but rather on the basis of three critical issues which must be objectively determined before the adoption of a given culture. He identified the contextual issues as including the environment in which the business operates the leadership style of its leaders and, its management practices or formal socialization process. In the light of this, Wilson (2001) argues that the nature of environment where the organization conducts its business goes a long way in determining its choice of culture. For example, an organization operating in a turbulent environment will not want to adopt the culture that emphasize too much bureaucracy in its structural configuration in order to allow its employees some level of autonomy and discretion in an unpredictable business environment and such would rather enthrone organic structure kind of organization behavior.

Again, the type of culture an organization adopts and promotes is also dependent on its managers' leadership styles. This is because it is its leaders that conceive and entrench their vision, beliefs and values before externalizing same in the organizations (Umrani, Shah, Memon \& Samo, 2017). Therefore, whatever that is not in line with their personal creed will be ignored no matter how essential it might be in the pursuit of the organization's goal. Beyond leadership style, management practices and formal socialization processes are also forces that shape the development of organizational culture. According to Wilson (2001), these encompass all the policies and procedures articulated to manage organization in a particular way. For instance, management approaches to decision making at all level of the organization, management's leadership style, management orientation towards technology, financials, and work improvement systems etc. However, these policies and procedure may encourage or discourage the emergence of a strong culture.

\section{Taxonomies of Organizational Culture}

Drawing from Denison (1990) organizational culture is characterized by the following four elements: involvement, consistency, adaptability and mission. We adopted these taxonomies because of their perceived wider implications on organizations' resilience and commitment to its very existence. Specifically in this study, emphasis is laid on the following three as discussed below.

Involvement: This is a cultural component that tends to explain the extent to which members of the organization are allowed to participate in decision-making processes. To buttress this point, Delery and Shaw (2001) refers involvement as a process designed to provide employee with the opportunity to influence and take part in decision making on issues which affect them. Bendix (2001) stated that involvement emphasizes the need for cooperation between managers and subordinates in terms of decision-making processes of management. Kim et al. (2010) also maintains that creating the atmosphere for employees to make constructive contribution on how they will execute their tasks while cheering their effort is assumed to be crucial for group cohesiveness. Therefore, according employees some level of participation in the determination of issues that affect their work creates a sense of ownership and responsibility in them (Abdullah, Musa \& Azis, 2017). 
Adaptability: This may be seen as the capability of an organization to respond to unexpected changes in its operating environment. Such response is typically observed whenever the leadership of an organization makes internal changes in its processes and systems to remain stable. According to Cohen and Levinthal (1990) adaptability is associated with the organization's ability to expect and respond to threats and latent opportunities by influencing its current situation to its advantage (Cohen \& Levinthal, 1990). In the same vein Denison (2007) viewed it as the process of transforming the demands of business operating environment into action. This explains that to remain in business and also make profit, organizations need to continuously adapt itself to the changing nature of their operating environment (Amah \& Baridam, 2012), and Daft (1998) puts it that environmental complexity is a vital contingency for organizational structure and internal policies such culture. On this note, organizations most have internal behaviors or policies imbedded in its core culture that encourages adaptation.

Mission: The focus of this cultural element is that it expresses in clear terms the core purpose of the organization to its members and why it is considered sacrosanct by the organization. According to Aluko, Odugbaesan, Gbadamosi and Osuagwu ((2004), the mission of the organization is an enduring statement of interest which sets the organization apart from other organization in the same line of business. It is strategic in nature and emphasizes stability and direction which guides the organization to manage relations with the outside world. Thus, reinforcing Oghojafor, Olayemi and Okonji's (2011) argument that the adoption of mission statements is not only as mere "slogans" but a tool that open the employees' eyes to see their daily tasks and roles in the vision and mission in order to achieve laid out goals. In other words, it means that a good mission must have clear objectives and direction that must continuously channel employees towards the achievement of set organizational goals. The measurement of an organization's success is mainly based on how well such an organization executes its set mission, as expressed in the crafted mission statement.

\section{Corporate Social Responsibility (CSR)}

The advocacy for corporate social responsibility entails that organization should try as much as possible to provide solution to societal problems while pursuing their primary economic objective. Consequently, the concept has over the years been espoused in diverse ways by different scholars and management practitioners. Skeptics perceive it as anti-capitalism (Adamol Ekun \& Ekundayo, 2007), while proponents view it as a mechanism which enthrones business and society relationships, which in turn promotes conducive operating environment required for optimal business performance in the long run. According to Sheehy (2015), corporate social responsibility is a management practice with the aim of improving the dialogue concerning the social contribution of business. Steiner and Steiner (2000) allude that it involves the task of an organization to make wealth by adopting strategies that would protect and enhance societal assets. It is also the commitment of an organization to contribute to sustainable economic prosperity, working with employees and its host community and the society at large to advance quality of life in ways that are both beneficial to business and good for development (Korkchi \& Rombaut, 2006). However, to us in this study, CSR is linked with business practices which tend to think and act beyond the primary purpose of business floatation (profit maximization) to engaging in actions that promote ecological sustainability and other social welfare programs (e.g. donations to people in need, community welfare support etc.)

In synchrony with the above views, organizations by their very existence can be viewed as entering into a social contract that obligates them to factor in the interests of the society when 
making decisions (Andreasen \& Drumwright, 2001), regarding their operational logic. Doing this practically affords the organization the opportunity of creating economic value for itself and at the same time strengthening its ties with community of stakeholders through social legitimacy validation. Thus, corporate social responsibility is increasingly being adopted to enhance firm and customer value. In contemporary business practices, CSR practices take different forms and shapes. According to Liu and Lin (2020), it may cover practices such as donations for who is in need, facilitation of community development and social problem resolving. In the same trend, Jamali and Mirshak (2007) earlier assertion captures it as practices like donations involving the orphans and handicapped, art and cultural development, sports and music events sponsorship and educational and learning programs assistance. The implication of these practices to organizations is that it not only allows them create economic value for themselves but also strengthen business-society interdependency, and creates healthy ecosystems. Lebura and Okoroba (2021) have argued that there are different perspectives to the practice of Corporate Social Responsibility especially in the emerging economies. These perspectives are CSR as philanthropy, CSR as a vehicle for filling institutional voids, CSR as public relations, CSR as a transactional relationship and CSR as a business strategy.

\section{Measures of Corporate Social Responsibility}

There are a number of measures of Corporate Social Responsibility as listed by scholars over time, but this paper utilizes Ghosh's (1993) categorization of five fundamental components of social responsibility as discussed below:

Responsibilities toward owners of business: This is considered as the primary responsibility of every business endeavor. This is because it is stressed that the primary purpose of every business venture is to make profit; therefore, the shareholders' interest must be guaranteed in the form a fair return on investment through quality dividends. This approach to CSR is anchored on the shareholders' theory which contends that organizations are not set up by the society but are owned privately by shareholders or investors (Hasnas, 1998). And as such, it is the prerogative of the organization to be accountable only to shareholders as they attempt to maximize the shareholders' wealth. Furthermore, in this perspective organization can only be socially responsible at the behest of the shareholders (Dang, Dang \& Danladi, 2014).

Responsibilities towards the employee: The focus of approach to CSR is to treat the employees of the organization as internal stakeholders of the organization. As internal stakeholders, employees can have a significant impact on both the development and implementation of CSR strategy (Dang, Dang \& Danladi, 2014). It therefore pays critical attention to employees' wages and salaries, working relations between leaders and subordinates, working conditions and environment as well as general employee welfare (Aluko, et al., 2000). This action is linked to the tenets of the stakeholder's theory which states that organizations should take into consideration their stakeholders when making corporate decisions (Donaldson \& Preston, 1995). It advocates that organizations should be concerned about the needs, hopes and influences of its stakeholders (Yakovleva, 2005).

Responsibilities towards consumers: The position of this CSR philosophy is that while businesses are in no doubt in business to do business, they must as a matter ethical issue ensures that they conduct their businesses in ways devoid of unfair trade practices. This implies that as an organization, in the midst of striving to actualize the objective of the business, customers' needs and safety should not be taken for granted. They must be provided with high quality of 
goods and services and at the right price without over shooting the profit margin. Boafo and Kokuma (2016) argued that ethical marketing practices must be given top priority and as such manipulation or falsely advertisement to potential consumers must be avoided. In this regard Dang, Dang and Danladi (2014) considers employees and customers' focus approach as the most adequate in CRS.

Responsibility toward government: This dimension is of the view that organizations while carrying out their statutory operation must do so in line with the prevailing business regulatory framework (Aluko, et al., 2004). This is as Lakin and Scheubel (2010) maintain that the idea of social responsibility of business tends to raise expectations that organizations should cooperate with government and pay their taxes accurately. This is evident when organization pay their taxes and dues fully, honestly as well as when due without any form of manipulation or evasion.

Responsibility towards the community and society: The essence of this form of corporate social responsibility is to acknowledge the interdependence between business and its host community. No business can separate itself from its operating environment and as such whatever happens or affect the environment also affect the business. Therefore, community relations become a necessity to maintain good affinity with the host community. However, this bond is required to be a mutually dependent one that results in community support, community loyalty, company goodwill, higher employee morale, etc. (Dang, Dang \& Danladi, 2014). The implication of this action according to Desatnik (2000) is that it builds good public image and employee morale, and breeds a sense of teamwork that is essential for long-term business success.

\section{Organizational Culture and Corporate Social Responsibility}

According to Liu and Lin (2020), environmental challenges covering pollution and global warming are identified as the principal issues that make organizations and individuals evaluate measures for preserving the environment. In pursuit of these measures, the spotlight is observably turning toward corporate social responsibility practices, especially as progressive organizations are now differentiating themselves through practice of CSR; although, this action is not devoid of controversies between the skeptics and the proponents of this practice. This is as a result of the fact that the concept has not been generally embraced, thus leading to lingering diverging views about its potential usefulness and applicability (Jamali \& Mirshak, 2007). But amid these controversies, proponents of CSR, both scholars and managers in practice have identified a strong interlace between organizational culture and sustained CSR practices. Packalén (2010) reveals that there is a strong association of organizational culture dimension on CSR practices. In the same manner, Yasin (2013) argues that one approach to advance business performance is to influence organizational culture through management activities, such as CSR.

For instance, the study of Papasolomou-Doukakis, Krambia-Kapardis and Katsioloudes (2005) which investigated CSR practices of Cypriot businesses found that managerial initiative, such as strong culture development serves as a key motive for the adoption of CSR by the business sector in Cyprus. Jamali and Mirshak (2007) in their study also affirm the potency of organizational culture as a precursor of CSR when they stated that cultural differences affect CSR dynamics with organization in different contexts exhibiting varied responses to this change in the business conduct landscape. More so, Hillman and Keim (2001) stressed that 
there has to be a nexus between organization culture and the societal, environmental and stakeholder expectations for a business to thrive. Therefore, we suggest that when organizations strive toward incorporating these identified issues into their cultural practices, they are practically demonstrating the nexus between culture and CRS practices, because these issues are well enshrined in CSR. Additionally, other studies have also shown that corporate social responsibility has a positive impact on organizational outcomes when it is integrated into its culture and business strategy (Jonker \& de Witte, 2006; Collier \& Esteban 2007).

According to Strautmanis (2007), social responsibility is an inner part of organizational culture. Organizational culture itself demonstrates the character of an organization through entrenched values, beliefs and assumptions (Galbreath, 2010). These are displayed through employee behaviors and decision-making, and also define the tendency and ability of the organization to carry out its operations either responsibly or irresponsibly (Melo, 2012). In this light, the philosophy of organizational culture influences the organization's propensity towards CSR practices and its sustainability (Kalyar, Rafi \& Kalyar, 2013). These similar trends of findings further give validity to the recent study of Liu and Lin (2020) when they argue that the implementation of CSR practices can be influenced by organizational culture. In their study, they revealed that organizational attributes such as the green culture practice reinforces an organization's external stakeholder-favorable behaviors, such as CSR practices.

This is as green organizational culture demands that the people and organizations need to have a cultural transformation for the collective awareness of their collective actions toward stakeholders and environment (Aliyu, Rogo \& Mahmood, 2015). It is seen as a practice that mostly focuses on realizing and obtaining the ecological balance (Mohezara, Nazria, Kaderb, Alib \& Yunusb, 2016), which is a strong aspect of CSR advocacy. Consequently, upon these observable favorable implications, Firoz and Abinakad (2016) opine that a number of organizations are now restructuring their cultures to accommodate new factors on issues such as environmental protection practices, behavior, and attitude related to environmental problems solving. This is because such cultural practice promotes ecological development and sustainable economic growth based on politics, science and aesthetics (Galpin, Whitttington \& Bell, 2015). On this premise, we infer that through the incorporation of social responsibility practices into an organizational culture, organizations will achieve greater success as a product of sustainable mutual benefit.

\section{CONCLUSION AND RECOMMENDATIONS}

Given the findings made through the review of extant literature, the study concludes that corporate social responsibility practices by organizations is a form of voluntary organizational behavior towards the society which has the capacity to bring the organization cohesively close to its stakeholders and in the long run stimulate its goal attainment in a sustainable manner. More especially as a recent study supports that social consciousness is one of the factors determining the growth of the company (Yang \& Gong, 2020). The study also notes that without an organizational culture that recognizes societal welfare as a precursor of business success, CSR orientation will only amount to a theoretical exercise without been practiced. Therefore, we recommend that: i) Organizations while pursuing their primary goals should also embrace CSR; (ii) that organizations should identify stakeholders' needs before adopting any given CSR approach. 


\section{REFERENCES}

Abdullah, S., Musa, C.I. \& Azis, M (2017). The effect of organizational culture on entrepreneurship characteristics and competitive advantage of small and medium catering enterprises in Makassar. International Review of Management and Marketing, 7(2), 409414.

Adamolekun, W. \& Ekundayo, T. (2007). Interactive public relations. Ibadan-Nigeria: Spectrum Books Limited.

Aliyu, M. S., Rogo, H. B., \& Mahmood, R. (2015). Knowledge management, entrepreneurial orientation and firm performance: the role of organizational culture. Asian Social. Science. 11(1), 140-190.

Aluko, M., Odugbaesan, O., Gbadamosi, G., \& Osuagwu, L. ((2004). Business policy and strategy ( $3^{\text {rd }}$ edn.).,Longman Nigeria Plc

Amah, E. \& Baridam, D. (2012). Adaptability and organizational effectiveness: A study of the Nigerian banking industry. International Journal of Business and Management Tomorrow, 2(3), 122-131.

Andreasen, A. \& M. Drumwright (2001). Alliances and Ethics in Social Marketing, in A. Andreasened. In Ethical Issues in Social Marketing (Georgetown University Press, Washington, DC).

Bendix, S. (2001). Industrial relations in South Africa ( $4^{\text {th }}$ ed.). Lansdowne: Juta.

Boafo, N. D., \& Kokuma, D.A. (2016). The impact of corporate social responsibility on organizational performance: A case study of Vodafone Ghana Limited. European Journal of Business and Management, 8(3), 22-43.

Brooks, I. (2006). Organizational behavior: Individuals, groups and organization. Essex: Pearson Education Limited.

Cameron, K.S. \& Freeman, S.L. (1991). Cultural congruence, strength, and type: Relationships to organizational climate and culture. San Francisco: Jossey-Bass.

Cameron, K.S. \& Quinn, R.E. (1999). Diagnosing and changing organizational culture based on competing value framework. Reading, M.A: Addison - Wesley.

Chakraboisrty, S. (2010). Corporate social responsibility and society. Unpublished.

Cohen, W.M. \& Levinthal, D.A. (1990). Absorptive capacity: A new perspective on learning and innovation. Administrative Science Quarterly 35(1), 128-152.

Collier, J., \& Esteban, R. (2007). Corporate social responsibility and employee commitment. Business Ethics: A European Review, 16, 19-33.

Daft, R. L. (1998). Organisational theory and design, (6 $6^{\text {th }}$ ed.), Ohio: South-Western College Publishing.

Dang, D.Y., Dang, C.P. \& Danladi, M.Z. (2014). Corporate social responsibility and community relations in Nigeria: A case study of grand cereals limited. Issues in Business Management and Economics 2(7), 121-127.

Dasanayake, S. W. S.B. \& Mahakalanda I. (2008). A literature survey on organizational culture and innovation, Mehran Nejati. Azadeh Shafaei. Mostafa Nejatin (Eds.) Issues in global Business and Management Research: Proceedings of International online Conference on Business and Management (IOCBM 2008) Florida: Boca Raton, Florida, 539-550.

Denison, D. (2007). Denison consulting model. An Hunkong: Arbor Zurich Shanghai Press.

Denison, D. R. (1990). Corporate culture and organizational effectiveness. John Wiley \& Sons.

Desatnik, L. (2000). Corporate volunteering is good business. Cincinnati Business Journal, 6(2), 39-66. 
Donaldson, T. \& Preston, L.E. (1995). The stakeholder theory of the corporation: Concepts, evidence and implications. Academic Management Review, 20(1), 65-91.

Firoz, N. M., \& Abinakad, M. (2016). Food Safety and ethics in foreign markets. Conflict Resolution \& Negotiation Journal 4 (3) 62-74.

Frankental, P. (2001). Corporate social responsibility - A public relations invention? Corporate communications. An International Journal 6(1), 18-23.

Freeman, R. E (1984). Strategic management -A stakeholder approach. Cambridge: Cambridge University Press.

Galbreath, J. (2010). Drivers of corporate social responsibility: The role of formal strategic planning and firm culture. British Journal of Management, 21(2), 511-525.

Galpin, T., Whitttington, J. L., and Bell, G. (2015). Is your sustainability strategy sustainable? creating a culture of sustainability. Corp. Gov. Int. J. Bus. Soc. 15, 1-17.

Grenberg, D. \& Baron, K. (2000). Assessing construct validity in organizational research. Administrative Science Quarterly, 1(2), 50-63.

Hasnas, J. (1998). The normative theories of business ethics: A guide for the perplexed. Business Ethics Quarterly, 8(1), 19-42.

Hillman, A., \& Keim, G. (2001). Shareholder value, stakeholder management, and social issues: what's the bottom line?, Strategic Management Journal, 22(2), 125-39.

Jamali, D. \& Mirshak, R. (2007). Corporate social responsibility (CSR): Theory and practice in a developing country context. Journal of Business Ethics, 72(2),243-262.

Jonker, J. \& de Witte, M. (2006). Management models for corporate social responsibility. New York: Springer.

Kalyar, M. N., Rafi, N. \& Kalyar, A. N. (2013). Factors affecting corporate social responsibility: An empirical study. Systems Research and Behavioral Science, 30(4), 495-505.

Kessapidou, S., \& Varsakelis, N. C. (2002). The impact of national culture on international business performance: The case of foreign firms in Greece. European Business Review, 14(4), 268-275

Kim, J., MacDuffie, J.P. \& Pil, F.K. (2010), Employee voice \& organizational performance: Team versus representative influence. Human Relations, 63(3), 371-394.

Koontz, H. \& Weihrich, H., (1999). Management: A global perspective (11 th ed.) Mexico McGraw Hill.

Korkchi, S., \& Rombaut, A. (2006). A case of private and public corporations. Unpublished.

Korkchi, S., \& Rombaut, A. (2006). Corporate social responsibility. A case of private and public corporations; Unpublished.

Lebura, S. \& Okoroba, I.A. (2021). Corporate social responsibility: Definitions and practice in emerging economies. In Yasser, Q.R. \& Al-Mamun, A. (Eds.) Transforming corporate governance and developing models for board effectiveness (pp.112-135). IGI global.

Lee, S. K. J., \& Yu, K. (2004). Corporate culture and organizational performance. Journal of Managerial Psychology, 19(4), 340-359.

Liu, X. \& Lin, K. L. (2020) Green Organizational Culture, Corporate Social Responsibility Implementation, and Food Safety. Frontier. Psychology, 11(1), 585435.

McKinnon, J. L., Harrison, G. L., Chow, C. W., \& Wu, A. (2003). Organizational culture: Association with commitment, job satisfaction, propensity to remain, and information Sharing in Taiwan. International Journal of Business Studies, 11(1).

Melo, T. (2012). Determinants of corporate social performance: The influence of organizational culture, management tenure and financial performance. Social Responsibility Journal, 8(1), 33-47. 
Mensah, H. K. (2017). The effect of corporate social responsibility on organizational commitment of employees of rural and community banks in Ghana. Journal of Cogent Business and Management, 4(1), 60-75.

Mohezara, S., Nazria, M., Kaderb, M. A. R. A., Alib, R., \& Yunusb, N. K. M. (2016). Corporate social responsibility in the malaysian food retailing industry: An exploratory study. Int. Acad. Res. J. Soc. Sci. 2, 66-7.

O'Reilly, C. A., \& Chatman, J. A. (1996). Culture as social control: Corporations, cults, and commitment. Research in Organizational Behavior, 18(18), 157-200.

Oghojafor, B. E. A., Olayemi, O. O. \& Okonji, P. S. (2011). Enhancing organization's performance through effective vision and mission. Chinese Business Review, 10, 10711075.

Packalén, S. (2010). Culture and sustainability. Corporate Social Responsibility and Environmental Management, 17(2), 118-121.

Papasolomou-Doukakis, I., Krambia-Kapardis, M., \& Katsioloudes, M. (2005). Corporate social responsibility: The way forward? maybe not, European Business Review. 17(3), 263-279.

Robbins, S. P., dan Judge (2008). Perilaku organisasi: Organizational behaviour, Edisi 12. Jakarta: Salemba Empat.

Robbins, S. P., DeCenzo, D. A. \& Coulter, M. (2011). Fundamentals of management $\left(7^{\text {th }}\right.$ edn.)., Pearson Education, Upper Saddle River, New Jersey.

Schein, E. H. (1990). Organizational culture, American psychologist, 45, 109-119.

Sheehy, B. (2015). Defining CSR: Problems and solutions. Journal of Business. Ethics 131, 625-648.

Strautmanis, J. (2007). Acquiring corporate social responsibility approach through business study process. Riga: University of Latvia.

Umrani, W.A., Shah, S.M.M., Memon, P.A. \& Samo, A. H. (2017). Organizational culture and business performance: An empirical investigation in the Pakistani context. International Journal of Academic Research in Economics and Management Sciences, 6(1), 87-89.

Wobodo, C. C., \& Asawo, S. P., Asawo, S. (2018). Knowledge sharing and employee resilience in tertiary institutions in Port Harcourt. Nigeria Business and Social Review, 9(2), 1-16.

Yakovleva, N. (2005). Corporate social responsibility in the mining industries. Hamshire: Ashgate Publishing Limited.

Yang, X., \& Gong, P. (2020). Marketing strategy of green agricultural products based on consumption intention. Agriculture Fores. Economical Management. 3(3), 16-24

Yilmaz, C., \& Ergun, E. (2008). Organizational culture and firm effectiveness: An examination of relative effects of culture traits and the balanced culture hypothesis in an emerging economy. Journal of World Business, 43(3), 290-306. 